Original article

\title{
Estimating the foliage area of Maritime pine (Pinus pinaster Ait.) branches and crowns with application to modelling the foliage area distribution in the crown
}

\author{
Annabel Portéa,, Alexandre Bosc ${ }^{\mathrm{a}}$, Isabelle Champion ${ }^{\mathrm{b}}$ and Denis Loustau ${ }^{\mathrm{a}}$ \\ ${ }^{a}$ INRA Pierroton, Station de Recherches Forestières, Laboratoire d'Écophysiologie et de Nutrition, \\ BP. 45, F-33611 Gazinet Cedex, France \\ ${ }^{\mathrm{b}}$ INRA Laboratoire de Bioclimatologie, BP. 81, F-33833 Villenave d'Ornon, France
}

(Received 26 August 1998; accepted 4 October 1999)

\begin{abstract}
Destructive measurements of architecture and biomass were performed on 63 trees from three Pinus pinaster stands (5, 21 and 26 year-old) in order to determine the quantity and distribution of foliage area inside the crown. Allometric equations were developed per site and needle age, which allowed to correctly calculate $\left(R^{2}=0.71\right.$ to 0.79$)$ the foliage area of a branch, knowing its basal diameter and its relative insertion height in the crown. Using these equations, we estimated total crown foliage area. A non-linear function of tree diameter and tree age was fitted to these data $\left(R^{2}=0.82\right.$ and 0.88$)$. On the 5 and 26 year-old stands, we combined the branch level models and the architectural measurements to develop probability functions describing the vertical and horizontal foliage area distributions inside the crown. The parameters of the beta functions varied with needle and stand age, foliage being located mostly in the upper and outer part of the crown for the adult tree, whereas it was more abundant in the inner and lower parts of the crown in the 5 year-old trees. A simple representation of crown shape was added to the study, so that knowing tree age and diameter, it could be possible to fully describe the quantity of foliage area and its localisation inside a maritime pine crown.
\end{abstract}

maritime pine / foliage area / foliage distribution / allometric relationship

Résumé - Estimation de la surface foliaire de branches et de houppiers de Pin maritime (Pinus pinaster Aït.) et son application pour modéliser la distribution de la surface foliaire dans le houppier. Afin de déterminer la quantité et la distribution de la surface foliaire dans un houppier de pin maritime, nous avons réalisé une analyse destructive de l'architecture et de la biomasse de 63 arbres issus de trois peuplements âgés de 5,21 et 26 ans. Des équations allométriques par peuplement et année foliaire permettent de calculer correctement $\left(R^{2}=0,71\right.$ à 0,79$)$ la surface foliaire d'une branche connaissant son diamètre et sa hauteur relative d'insertion. L'utilisation de ces équations a permis d'estimer la surface foliaire totale du houppier. Un modèle arbre correspondant à une fonction puissance du diamètre de l'arbre et de l'inverse de son âge a été ajusté sur ces valeurs $\left(R^{2}=0,80\right.$ et 0,88$)$. D'autre part, la combinaison des modèles branches et des mesures architecturales a permis de paramétrer des fonctions de type bêta, sur les sites de 5 et 26 ans, décrivant les distributions verticales et horizontales de la surface foliaire dans le houppier. Leurs paramètres variaient avec l'âge du site et de la cohorte : le feuillage étant localisé dans la partie supérieure et extérieure du houppier chez les arbres adultes, et davantage vers le bas et l'intérieur de la couronne des arbres de 5 ans. Une représentation simplifiée de la forme du houppier a été ajoutée à l'établissement des profils de surface foliaire afin que la connaissance de l'âge et du diamètre à 1,30 $\mathrm{m}$ d'un pin maritime suffisent à établir une description quantitative et qualitative de son feuillage.

pin maritime / surface foliaire / distribution foliaire / relations allométriques

* Correspondence and reprints

Tel. (33) 05579790 34; Fax. (33) 05566805 46; e-mail: Annabel.Porte@pierroton.inra.fr 


\section{INTRODUCTION}

Appreciation of forest structure is determinant in studying stand growth and functioning. In forestry, stand structure mostly refers to the relative position of trees and to stem and crown dimensions. However, estimating the amount and the location of the tree foliage area is a critical point in order to model its biological functioning $[17,27,40]$. Since direct measurements of foliage distribution are nearly impossible to perform in forest stands, they have been replaced by sampling procedures. At the stand level, the plant area index (including the projected area of all aerial elements of the stand) can be assessed from light interception measurements. However, such a technique does not describe the foliage spatial distribution. Allometric relationships constitute an accurate tool, many times used to estimate and predict the amounts and the distributions of foliage or crown wood in trees $[1,3$, 39]. Foliage distributions can be required in light interception models [40], and coupled to $\mathrm{CO}_{2}$, vapour pressure and temperature profiles to determine canopy carbon assimilation.

In the Landes de Gascogne Forest, a general drying has been observed that resulted into a disappearing of lagoons (1983-1995: -49\%) and a lowering of the water table level up to $44 \%$. From these observations, scientists raised a new problematic [18]: how can we maintain the equilibrium of the Landes forest in terms of wood production without exhausting the natural resources? To enter such a question, we investigated upon the response of Maritime pine to water availability in terms of primary production and growth. To overcome the problem of duration which prevents from studying the whole life cycle of a forest, scientists have been developing models. Structure-function models provide a highly detailed description of tree functioning but require numerous parameters $[6,11,19,29,31]$. Pure statistical models are based on data measurements and quite easy to handle but they remain too empirical to be used as growth predictors in a changing environment [20, 21, 37]. In between, semi-empirical approaches were developed [1, 2, 23, 18] that lay on quite rough hypothesis when compared to real functioning. However, they permitted to describe complex processes in a simple way, and to build growth models sensitive to environmental conditions. As a necessary first step in the semi-empirical and ecophysiological modelling of Maritime pine (Pinus pinaster Aït.) growth in the Landes de Gascogne, we undertook the determination of stand foliage area amount and distribution. Previous studies on Maritime pine partially solved the problem [22]. First, they did not discriminate needles according to their age, which is an important factor regarding their physical and physiological characteristics $[5,30]$. Moreover, the study had only been done for a 16 year-old stand. Considering maritime pine, as the tree gets older, branches sprung at the top of the crown lower down. At the same time, they change their geometry and their amount of surface area.

Therefore, the first objective was to develop equations permitting to predict the needle area of a branch and of a tree, whatever stand age could be. We worked on a chronosequence of stands (5, 21 and 26 year-old stands) considered to represent the same humid Lande maritime pine forest at different ages. The second objective was to model foliage distribution in the crown to supply information to light interception and radiation use models that were under construction in the laboratory. Foliage area amounts were estimated using the developed allometric equations and coupled to architectural crown measurements in order to describe vertical and horizontal leaf area density profiles.

\section{MATERIAL AND METHODS}

\subsection{Stands characteristics}

The study was undertaken on two stands located $20 \mathrm{~km}$ Southwest of Bordeaux, France ( $\left.44^{\circ} 42 \mathrm{~N}, 0^{\circ} 46 \mathrm{~W}\right)$. They had an average annual temperature of $12.5^{\circ} \mathrm{C}$ and receive annual rainfall averaging $930 \mathrm{~mm}$ (1951-1990). The Bray and L sites were even-aged maritime pine stands originating from row seeding, with an understorey consisting mainly of Molinia (Molinia coerulea Moench.). Stand characteristics are summarised in table V. Since 1987, the Bray forest has been studied for water relations, tree transpiration and energy balance $[4,5,13$, $14,24]$.

\subsection{Data collection}

Caution: the term foliage area always refers to the allsided foliage area of the needles. Projected area only appears in leaf area index (LAI, $\mathrm{m}^{2} \mathrm{~m}^{-2}$ ) values and is calculated by dividing all-sided area by $(1+\pi / 2)$ which correspond to a projection assuming needles to be semicylinders. Symbols used are presented in table Al (Appendix 1).

Similar studies were done in 1990 and 1995 on the Bray site (21 and 26 year-old) and in 1997 on the L site (5 year-old). On the Bray site, diameter at breast height (DBH, cm, measured at $1.30 \mathrm{~m}$ high) was measured for each tree of the experimental plot (table $V, n=3897$ and 2920) whereas on the younger trees, only total height could be measured. Trees were studied for architectural and biomass measurements. In order to represent the stand distribution, we sampled 19 trees in 1990 and 
14 trees in 1995, according to their diameter at breast height (DBH, cm) and 30 trees in 1997 according to their height. In winter time (late November to February) the 21 and 26 year-old trees were fallen carefully to minimise the damage to the crowns, and the 5 year-old trees were pulled off the ground with a Caterpillar. The coarse roots were studied for architectural measurements [7, 8] and wood characteristics with regards to wind loading $[33,34]$. On the ground, the lengths $(L$, nearest $0.5 \mathrm{~cm})$ and the diameters $(D$, measured in the middle of the growth unit, nearest $0.1 \mathrm{~cm}$ ) of each annual growth unit of the trunks were measured (figure 1). The diameter of each living branch $\left(D_{10}, \mathrm{~cm}\right.$, measured at the nearest $0.01 \mathrm{~cm}$, diameter at about ten $\mathrm{cm}$ from the bole) was measured with an electronic calliper. Two branches per living whorl were selected for more detailed measurements (195 branches in 1990, 186 branches in 1995, 265 branches in 1997, for the stand). In 1995 and 1997, detailed architectural measurements were done on each sampled branch: branch length $\left(L_{\mathrm{b}}\right)$, chord length $(C)$, insertion angle between chord and bole $(\alpha)$ were measured; lengths $\left(L_{j}\right)$ and diameters $\left(D_{j}\right.$, measured in the middle of the growth unit) were obtained for all $2^{\text {nd }}$ order internodes (figure 1). Polycyclism of tree growth is an important phenomenon during early growth [16]. Therefore, on younger trees, we paid attention to describe this phenomenon: the first growth cycle of the annual growth unit is named $\mathrm{A}$, the second $\mathrm{B}$, etc. Branch analysis was done separately for each cycle because from the $2^{\text {nd }}$ cycle, growth tends to be less than during the $1^{\text {st }}$ annual flush. During all studies, one branch per pair was randomly selected for determination of foliage biomass. Branch foliage was separated into compartments according to needle age, the $2^{\text {nd }}$ order internode on which it was inserted and its order of ramification (figure 1). Needles located on the trunk were entirely collected. Foliage was oven-dried at $65{ }^{\circ} \mathrm{C}$ for $48 \mathrm{~h}$ and weighted. Ten needle pairs were randomly collected, per needle age class (1 to 3 year-old), per whorl and per tree, in order to determine their specific leaf area (SLA, $\mathrm{m}^{2} \mathrm{~kg}^{-1}$ ). The middle diameter and the length of each needle was measured to calculate its area assuming needles to be semi-cylinders. Their total dry weight (oven-dried at $65{ }^{\circ} \mathrm{C}$ during $48 \mathrm{~h}$ ) was measured, and SLA calculated as the ratio of needles area per their weight $\left(\mathrm{m}^{2} \mathrm{~kg}^{-1}\right)$. The foliage area of each compartment was estimated multiplying its dry weight with the corresponding SLA.

From November 1996 to January 1997, during an independent study, a set of 108 branches was collected from 10 trees (27 year-old) representative of the Bray site DBH distribution. $D_{10}$, total needle area per needle age were measured and SLA values calculated and used to estimate the branch foliage area, for one branch per whorl. This additional data set was used for testing the allometric relationships established in 1995 at the Bray site.

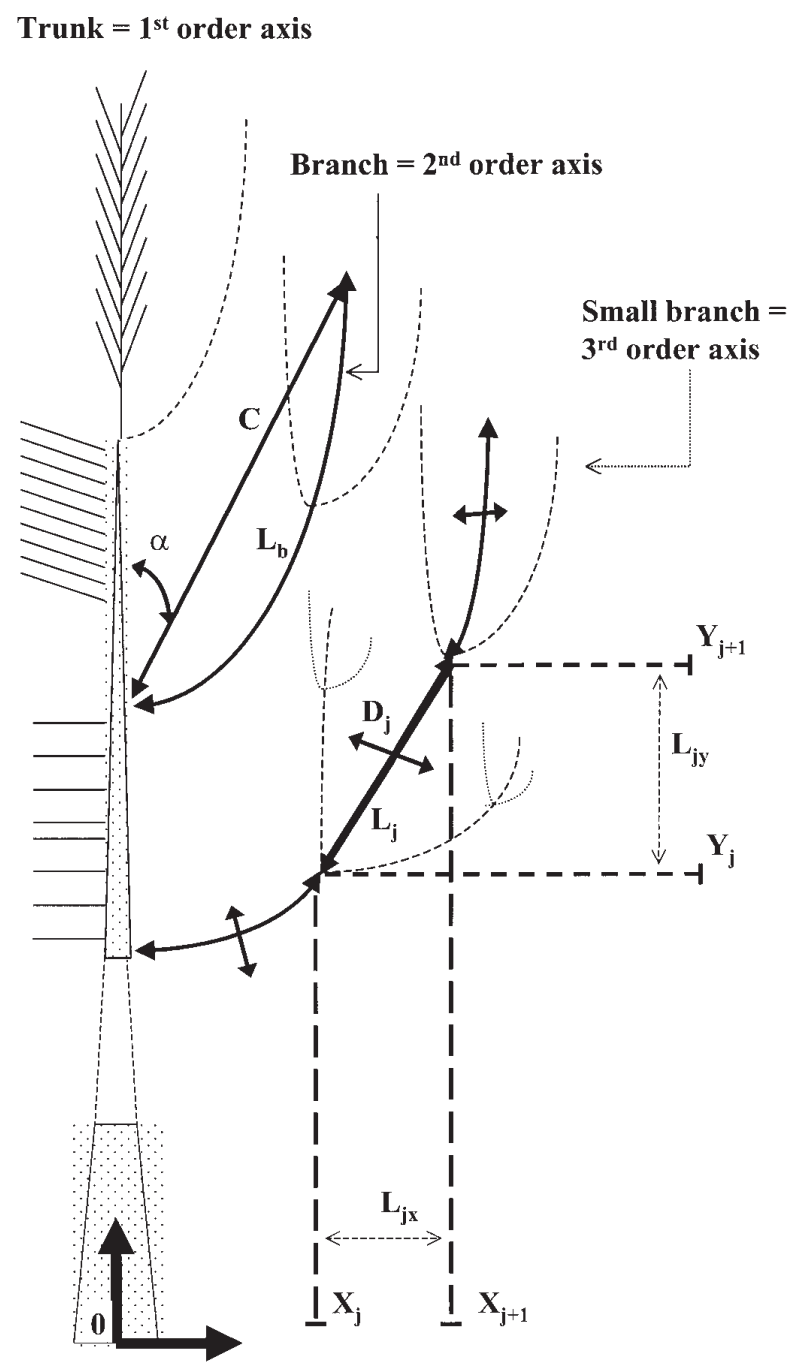

Figure 1. Diagram of a maritime pine presenting the detail of the architectural measurements done on the sampled branches. Branch length $\left(L_{\mathrm{b}}\right)$, chord length $(C)$, bole-chord angle $(\alpha)$, length $\left(L_{i}\right)$ and diameter $\left(D_{j}\right)$ of each internode of the branch. $X_{j}, X_{j+1}, Y_{j}, Y_{j+1}$ are the co-ordinates of the ends of the internode. The total foliage area borne by the internode ( $2^{\text {nd }}$ order $)$ and the $3^{\text {rd }}$ order branches inserted on this internode was assumed to be uniformly distributed along $L_{j,}$ to determine the vertical distribution of foliage area, and uniformly distributed along $L_{j x}$ for the horizontal distribution of foliage area. 


\subsection{Statistical analysis}

Various linear and non-linear regression models were fitted to our data sets using the SAS software package (SAS 6.11, SAS Institute Inc., Cary, NC, 1989-1995). The choice of the final model was based on several criteria: best fitting on the sample population (characterised with adjusted $R^{2}$ values, residual sums of square, residual mean square, $F$ values of regressors, residual plots), the biological significance of the variables used as regressors, its simplicity (minimum number of regressors) and its use as an estimating tool when extrapolating to the total population. Multiple range tests were used to compare mean values (Student Newman Keuls). Means with the same letters are considered not to be significantly different at the $5 \%$ tolerance level.

\subsection{Distributions of foliage area density}

This part of the work was completed on the $5(L)$ and 26 year-old stands (Bray95). It was based on the following assumptions: (i) The vertical and horizontal distributions of foliage area density are independent of each other. (ii) The horizontal distribution of foliage area density is the same whatever the height in the crown.

For the horizontal profile, crown length was divided into ten slices for the Bray site, three slices for the $L$ site. The lower and upper slices were omitted and the following steps were made for each remaining slice. On each slice, normalised distances $\left(X_{\text {rel }}\right)$ were measured, with a length unit equal to the length of the slice radius, so that $X_{\text {rel }}$ varied between 0 from the stem to 1 on the crown periphery. Relative height $\left(H t_{\text {rel }}\right)$ was defined with 0 at the bottom of the crown, 1 at the top of the crown. We considered that a branch was equivalent to a circular arc, of length $L$, chord $C$, inserted with angle $\alpha$, at the height $H$, (Fig. 1) and constituted of $j=1$ to $\mathrm{n}$ internodes. The co-ordinates $\left(X_{j}, Y_{j}\right)$ of both ends of each internode $j$ were calculated using the length measurements of the internodes $\left(L_{j}\right)$. The orthogonal projection of internode $j$ (length $L_{j}$ ) on the vertical axis was calculated as $L_{j y}=$ $Y_{j+l}-Y_{j}$ and its orthogonal projection on the horizontal axis as $L_{j x}=X_{j+1}-X_{j}$. To each point $\left(X_{j}, Y_{j}\right)$ was associated a foliage area, $L A_{j}$ (needle age), equal to the sum of the leaf area bear by the woody axes inserted on this point ( $2^{\text {nd }}$ to $4^{\text {th }}$ order woody axes, needle age 1 to 3 ). It was normalised to needle area density, $N A D^{j}$, using the estimated crown (or layer) foliage area estimated with the allometric branch models. Finally, the normalised foliage area was assumed to be distributed uniformly along the normalised projection $L_{j x}$ or $L_{j y}$.
The vertical and horizontal foliage area profiles were fitted to a three or four parameters beta function ( $a 4$ can be fixed to one according to the shape of the distribution) using the non-linear procedure of the SAS software package (SAS 6.11, SAS Institute Inc., Cary, NC, 19891995): it calculated the minimum residual sum of leastsquare using the iterative method of Marquardt.

$$
N A D=a 1 \cdot y^{a 2} \cdot(a 4-y)^{a 3}
$$

where $y$ is the normalised dimension of the crown, either $H t_{\text {rel }}$ or $X_{\text {rel }}$.

\section{RESULTS}

For each stand age, three needle age cohorts were found on every tree, exceptionally four year-old needles remained on some branches of the two oldest stands. On the 5 year-old stand ( $L$ site), three year-old needles represented less than $1 \%$ of the total sampled leaf area, therefore they were ignored in the distribution study. One year-old needles represented $60 \%$ of the total needle area (table I). For the 21 and 26 year-old stands (Bray 90 and 95), one year-old needles formed a smaller proportion of the total area, with 42 and $48 \%$ respectively, whereas three year-old needles reached 22 and $8 \%$ of the total area, for each stand, respectively. Distribution of leaf area according to the woody axis order of ramification (table I) showed the strong contribution of $3^{\text {rd }}$ order branches $(54 \%)$ to total leaf area for the older stand, whatever the needle age was. On the contrary, it showed the importance of $1^{\text {st }}$ and $2^{\text {nd }}$ order axis for the 5 year-old stand $(16+38=54 \%)$.

\subsection{Branch-level foliage area model}

The highest linear correlation between branch foliage and branch characteristics occurred with the product variable $D_{10}^{2} \times H t_{\text {rel }}(R=0.81$ to 0.90$)$ for the one yearold needle of every stand, and for the two year-old needles of the two oldest stands. Squared $D_{10}$ and relative height into the crown were the recurrent explicative variables strongly related to branch foliage area ( $F$ value corresponding to an error probability inferior to 0.001). Some variables such as the length of the trunk growth unit occasionally appeared as explicative variables of branch foliage variability, but they demonstrated a low significant effect and were highly specific of both the needle and stand ages. The different models investigated were either linear or non-linear relationships, with more or less numerous variables and finally exhibited quasiequivalent fittings on the data (in terms of sum of squares, residual mean squares, $F$ and $R^{2}$ values) and 
Table I. Distribution of the measured foliage area according to the order of the bearing axis $(1=$ trunk, $2=$ branch, $3=$ branch on the branch etc.) and to needle age, in percent of the total measured area. Specific leaf area values (SLA, $\mathrm{m}^{2} \mathrm{~kg}^{-1}$ ) per needle age. Values in parenthesis are standard deviations of the mean values. Values with the same letter are not significantly different $(\alpha=0.05)$.

\begin{tabular}{|c|c|c|c|c|c|c|}
\hline & \multirow[b]{2}{*}{ Stand } & \multirow[b]{2}{*}{ Order } & \multicolumn{4}{|c|}{ Needle age } \\
\hline & & & 3 year-old & 2 year-old & 1 year-old & all \\
\hline \multirow{11}{*}{$\begin{array}{l}\text { Foliage area } \\
(\%)\end{array}$} & 5 year-old stand & 1 & 0.45 & 5.45 & 10.00 & 15.90 \\
\hline & $(\mathrm{L})$ & 2 & 0.22 & 13.52 & 23.88 & 37.62 \\
\hline & & 3 & 0.25 & 17.44 & 25.75 & 43.44 \\
\hline & & 4 & 0 & 1.88 & 1.15 & 3.03 \\
\hline & & all & 0.92 & 38.30 & 60.78 & - \\
\hline & $\begin{array}{l}21 \text { year-old stand } \\
\text { (Bray 90) }\end{array}$ & all & 21.51 & 36.68 & 41.81 & - \\
\hline & 26 year-old stand & 1 & 0.21 & 2.38 & 2.69 & 5.27 \\
\hline & (Bray 95) & 2 & 1.73 & 12.31 & 14.34 & 28.39 \\
\hline & & 3 & 5.48 & 23.35 & 25.56 & 54.39 \\
\hline & & 4 & 0.81 & 5.56 & 5.58 & 11.95 \\
\hline & & all & 8.23 & 43.60 & 48.17 & - \\
\hline SLA & 5 year-old stand & - & - & $\begin{array}{l}9.11^{\mathrm{b}} \\
(1.58)\end{array}$ & $\begin{array}{l}8.68^{b} \\
(1.48)\end{array}$ & - \\
\hline$\left(\mathrm{m}^{2} \mathrm{~kg}^{-1}\right)$ & 26 year-old stand & - & $\begin{array}{l}6.57^{\mathrm{a}} \\
(0.81)\end{array}$ & $\begin{array}{l}6.82^{\mathrm{a}} \\
(1.33)\end{array}$ & $\begin{array}{l}7.69^{\mathrm{a}} \\
(1.55)\end{array}$ & - \\
\hline
\end{tabular}

similar residuals graphs (data not shown). The choice of the final model lay on the facts that it demonstrated high significant $F$ values and equivalent residual mean squares and residuals distributions when compared to the others. The linear functions that were explored presented indeed smaller residual mean squares than the final model, but often produced negative values for small diameter values. Therefore, linear models were not appropriate since we aimed at using the final relationship to estimate foliage area for diameters ranging 0 to $6 \mathrm{~cm}$. The final model matched also our requirements of (i) being a simple and useful tool. It required only two variables, branch diameter and branch relative height in the crown, which were non destructive measurements that can be rapidly and easily obtained in any forest. It only required three parameters which also facilitated its parameterisation compared to more complex models. (ii) This model was still empirical but variables and parameters had a biological significance: this point will be developed in the discussion. The allometric model of branch foliage retained corresponded to the following equation:

$$
\operatorname{BrLA}(\text { age } i)=\left(a 2 \cdot D_{10}^{2} \cdot H t_{\text {rel }}+a 3 \cdot D_{10}^{2}\right)^{a 1}
$$

with $\operatorname{BrLA}(i)$ being branch leaf area of needle cohort of age $i$ ( 1 or 2 year-old) (table II). The final model residual mean square ranged from 0.03 to $0.27\left(\mathrm{~m}^{2}\right)^{2}$, the best one occurring for the two-year old needles area on the youngest stand.

Figure 2 presents the branch foliage area calculated using equation (2) versus the branch area data measured on all three stands, for the one and two year-old needles. For branch foliage area lower than $1 \mathrm{~m}^{2}$, variance on the estimates was large comparatively to the estimated value, whereas between 1 and $2.5-3 \mathrm{~m}^{2}$, the fittings were very satisfying. Then at the upper end of the range (over $3 \mathrm{~m}^{2}$ ), the model resulted in slightly underestimating the biggest branch area. The model was a little better for the two year-old needles (figure $2, R^{2}=0.76$ ). As a whole, the models explained 71 and $76 \%$ of the branch needle area variability. The use of one single branch model for the three stands altogether (table II) gave as satisfying fittings on the whole set than when using separate fittings for each stand. But looking at each stand separate$1 y$, it resulted in overestimating the needle area of the younger stand branches and underestimating the branch area of the older stand. Different fittings for each site were then elected as the more adapted models (table II). No clear tendency in the parameters $(a 1, a 2, a 3)$ could be driven out of the study. Parameter $a 3$ tended to increase with stand age whereas parameter $a 2$ tended to decrease regularly for both needle ages. Parameter $a 1$ tended to increase with stand age for the younger needles and no tendency appeared for the two year-old needles. Neither of these differences between site was significant. 
Table II. Parameters of the model selected to estimate individual branch foliage area by needle age ( 1 or 2 year-old) as a function of branch dimensions and relative height in the canopy. $\operatorname{BrLA}(i)=\left(a 1 * D_{10}^{2} * h t_{\text {rel }}+a 2 * D_{10}^{2}\right)^{a 3}$, with $\operatorname{BrLA}(i)$, branch foliage area of needle age $i, D_{10}$, branch diameter at ten $\mathrm{cm}$ from insertion $(\mathrm{cm}), H t$ rel, relative height of insertion of the branch in the crown $(0=$ bottom of the crown, $1=$ top of the crown). Polycyclism code is defined as A = first cycle of the year, all $=$ all cycles mixed. Numbers in parenthesis indicate the asymptotic standard error on the estimate.

\begin{tabular}{|c|c|c|c|c|c|c|}
\hline Stand & Needle age & Polycyclism & $a 1$ & $\begin{array}{c}\text { Parameter } \\
\quad a 2\end{array}$ & $a 3$ & $\mathrm{RMS}^{*}$ \\
\hline \multirow[t]{2}{*}{ Bray 95} & 1 year-old & A & $0.235(0.019)$ & $0.031(0.005)$ & $1.290(0.082)$ & 0.27 \\
\hline & 2 year-old & A & $0.153(0.014)$ & $0.051(0.004)$ & $1.319(0.085)$ & 0.20 \\
\hline \multirow[t]{2}{*}{ Bray 90} & 1 year-old & A & $0.325(0.025)$ & $0.039(0.007)$ & $1.112(0.079)$ & 0.11 \\
\hline & 2 year-old & A & $0.221(0.017)$ & $0.065(0.005)$ & $1.335(0.081)$ & 0.09 \\
\hline \multirow[t]{2}{*}{$\mathrm{L}$} & 1 year-old & all & $0.614(0.036)$ & $0.051(0.013)$ & $1.102(0.061)$ & 0.05 \\
\hline & 2 year-old & all & $-0.232(0.044)$ & $0.243(0.016)$ & $0.936(0.071)$ & 0.03 \\
\hline \multirow[t]{2}{*}{ L + Bray $95+$ Bray 90} & 1 year-old & all & $0.348(0.017)$ & $0.030(0.005)$ & $0.881(0.031)$ & 0.15 \\
\hline & 2 year-old & all & $0.194(0.013)$ & $0.061(0.004)$ & $0.994(0.038)$ & 0.13 \\
\hline
\end{tabular}

*RMS, residual mean square.

For the two older stands, three year-old needle area was hardly related to tree characteristics. Indeed, the strongest correlation occurred with branch diameter but it only explained a small part of the variability encountered $(R=0.36$ for the 26 year-old stand, 0.70 for the 21 year-old stand). As we could not find any satisfying allometric model, we decided to set the three year-old needle area equal to its proportion in the total needle area of the sampled branches (table I).

To check the allometric equations that we established on the 26 year-old stand data set (table II), we applied them to estimate the needle area of branches collected on 27 year-old maritime pines. Figure 3 presents the estimated foliage area versus the measured foliage area of these branches. The fittings were satisfying, performing slightly better for the two year-old needles (slopes equal to $1.04, R^{2}=0.81$ for the two year-old needles, $R^{2}=0.72$ for the one year-old needles). As a consequence of the high variability in needle fall, the 3 year-old needles could not been estimated.

\subsection{Crown level foliage area}

The total crown foliage area $(\operatorname{CrLA}(i)$, with $i=$ needle age) of each sampled tree was estimated using the branch level models developed for each stand (Eq. 2). Values ranged from $1.4 \mathrm{~m}^{2}$ to $56.17 \mathrm{~m}^{2}$ for the 5 year-old trees, from $14.45 \mathrm{~m}^{2}$ to $93.45 \mathrm{~m}^{2}$ for the 21 year-old trees, and from $41.26 \mathrm{~m}^{2}$ to $174.95 \mathrm{~m}^{2}$ for the 26 yearold trees (table III). The three year-old needle area was corresponding to mean values of $0.89,17$ and $7 \%$ of the total area for the 5, 21 and 26 year-old trees, whereas the one year-old needles accounted for 59.8, 45.2 and $49.8 \%$ of the total foliage area for the 5, 21 and 26 year-old trees. The ratio of total crown leaf area to sapwood area under the living crown was ranging between 0.27 and $0.89 \mathrm{~m}^{2} \mathrm{~cm}^{-2}$ for all three stands. It was significantly higher for the younger stand (table III).

Linear and non-linear models were tested on each stand separately, and on all three stands together. The best model to estimate crown foliage area corresponded to a non-linear function of tree diameter and tree age:

$$
\text { CrLA }(\text { age } i)=b 1 . \frac{D^{b 2}}{{\text { tree } \operatorname{age}^{b 3}}^{32}}
$$

with $\operatorname{CrLA}(i)$ being the crown leaf area of the needle cohort of age $i$ ( 1 or 2 year-old) (table IV), $D$ corresponding either to the diameter at breast height $(\mathrm{DBH})$ or the diameter under the living crown (DLC). No other variables such as tree height or crown length were significant. The model was significantly different with needle age, but not with stand age. The use of diameter at breast height (or diameter at the tree basis for the $L$ stand), instead of diameter under the living crown, resulted in equivalent fittings on the data (data not shown). Therefore DBH was preferred to DLC since it is much easier to measure at the stand level.

Figure 4 presents the crown foliage area estimated with the model described in equation (3), and parameterised on the three stands altogether, versus the crown area calculated using the branch level models developed 

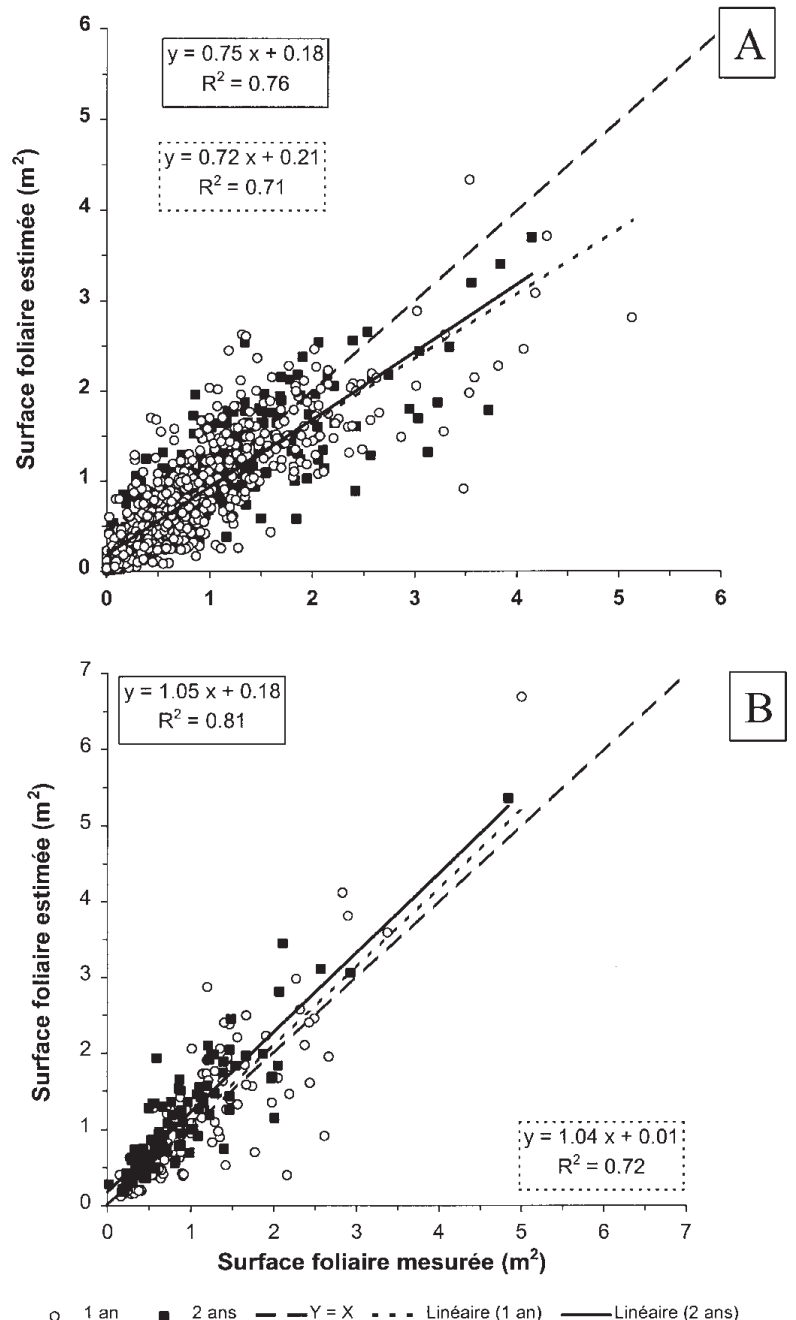

Figure 2. Estimated branch needle area versus measured branch needle area, in $m_{-}$. (A) Points correspond to data of the three stands, lines to linear adjustments on the points. Estimations were done with the branch level models adjusted on each stand separately. (B) Points correspond to the validation data set from the 27 year-old stand, lines to linear adjustments on the points. One year-old needles (o), (---). Two yearold needles $(\square),(-)$. The broken line $(--)$ corresponds to the equation $Y=X$.

for each stand. Fittings were very satisfying, for both needle age, with slopes close to 1 and $R^{2}$ greater than 0.80 .

Simple models were also developed in order to rapidly estimate crown length and crown maximum radius (table IV). Crown dimensions were directly related to

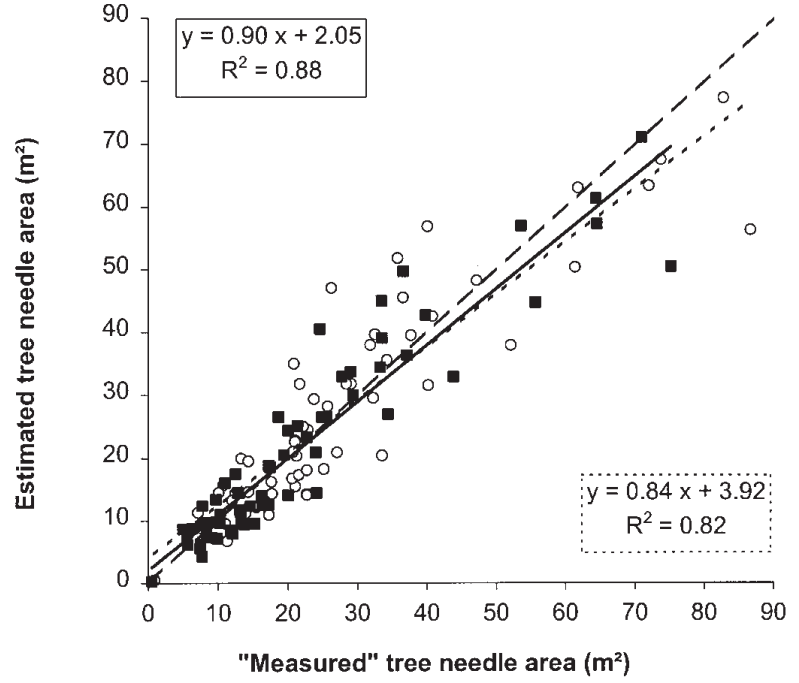

Figure 3. Tree needle area estimated with the crown level models (table IV, with DBH and age) versus "measured" tree needle area in $\mathrm{m}^{2}$. The "measured" values correspond to the estimations of tree needle area using the branch models presented in table III. Points correspond to data of the three stands, lines to linear adjustments on the points: 1 year-old needles $=(0),(---) ; 2$ year-old needles $=(\square),(-)$. The broken line (- - corresponds to the equation $Y=X$.

DBH, without any difference among the stands. However, the model performed better for crown length (CrLgth) than for crown maximum radius (CrRad). On figures $5 A$ and $B$, each measured co-ordinates $\left(X_{j}, Y_{j}\right)$ were standardised and plotted altogether, for the 26 and 5 year-old stands. A 4-degree polynomial function was used to describe the data envelope curve; it corresponded to the standardised shape of 5 and 26 year-old maritime pine crowns. The main difference appeared between the stands: maximum radius appeared lower in the crowns of 26 year-old trees $(0.25-0.40$ of relative height) and it was more variable and located upper inside the crowns of the 5 year-old trees ( $0.35-0.60$ of relative height). Within one stand, crown shapes could be differing consecutively to one particular branch position, but globally remained within the same dimensional limits and could be considered equivalent from one tree to another.

\subsection{Stand level foliage area}

The stand LAI was calculated by dividing the stand foliage area by the stand area. For the 21 and 26 year-old stands, stand foliage area was calculated as the sum of the leaf area of each tree; the latter was estimated by 
Table III. Crown foliage area $\left(\mathrm{CrLA}, \mathrm{m}^{2}\right)$ estimated using the branch level models presented in table I, and ratio of crown foliage area to sapwood area at the base of the living crown $\left(\mathrm{m}^{2} \mathrm{~cm}^{-2}\right)$ according to the needle and the stand ages. Means are calculated on 14, 19 and 30 values for the Bray site in 1995, in 1990 and the L site, respectively. Means with the same letter are not significantly different $(\alpha=0.05)$.

\begin{tabular}{|c|c|c|c|c|c|c|}
\hline & \multirow[b]{2}{*}{ Stand } & \multirow[b]{2}{*}{ Needle age } & \multicolumn{4}{|c|}{ Estimated crown foliage area } \\
\hline & & & mean & SD & $\min$ & $\max$ \\
\hline \multirow{9}{*}{$\begin{array}{l}\text { CrLA } \\
\left(\mathrm{m}^{2}\right)\end{array}$} & \multirow[t]{3}{*}{ Bray 95} & 1 year-old & 50.89 & 22.79 & 20.98 & 86.74 \\
\hline & & 2 year-old & 44.08 & 20.19 & 17.21 & 75.25 \\
\hline & & 3 year-old & 7.60 & 3.44 & 3.06 & 12.96 \\
\hline & \multirow[t]{3}{*}{ Bray 90} & 1 year-old & 25.60 & 10.77 & 7.08 & 40.78 \\
\hline & & 2 year-old & 22.46 & 10.47 & 4.96 & 37.09 \\
\hline & & 3 year-old & 9.61 & 4.24 & 2.41 & 15.57 \\
\hline & \multirow[t]{3}{*}{$\mathrm{L}$} & 1 year-old & 17.78 & 6.97 & 0.89 & 33.51 \\
\hline & & 2 year-old & 12.13 & 5.35 & 0.51 & 24.08 \\
\hline & & 3 year-old & 0.27 & 0.11 & 0.01 & 0.51 \\
\hline \multirow{3}{*}{$\begin{array}{l}\text { Ratio CrLA / } \\
\text { sapwood area } \\
\left(\mathrm{m}^{2} \mathrm{~cm}^{-2}\right)\end{array}$} & Bray 95 & - & $0.42^{\mathrm{a}}$ & 0.07 & 0.31 & 0.58 \\
\hline & Bray 90 & - & $0.39^{\mathrm{a}}$ & 0.07 & 0.27 & 0.50 \\
\hline & L & - & $0.59^{b}$ & 0.13 & 0.37 & 0.81 \\
\hline
\end{tabular}

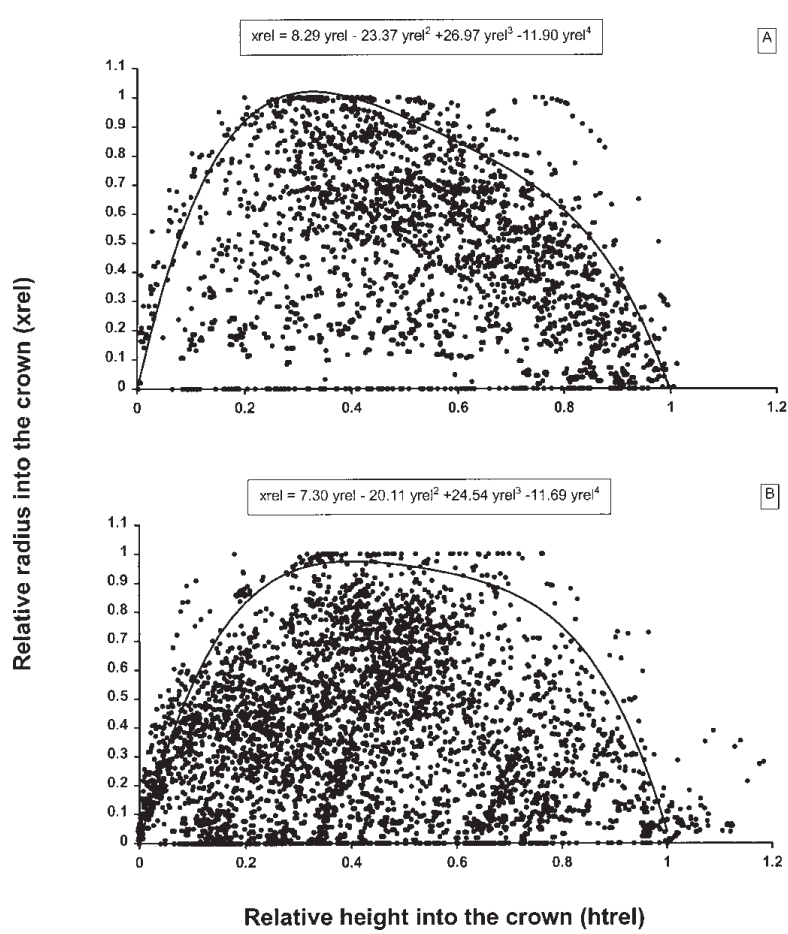

Figure 4. Relative crown radius as a function of relative height into the crown. (A) for the 26 year-old stand. (B) for the 5 year-old stand. Closed circles correspond to each measured point $\left(X_{j}, Y_{j}\right)$ standardised according to crown length and maximum radius, for all branches and trees together. The solid line represents the boundary curve on the measured points, of corresponding equation written on the graph. applying equation (3) with DBH as an explicative variable. For the 5 year-old stand, this method could not been used since we did not have diameter measurements for every tree. We simply multiplied the leaf area of each sampled tree by the number of trees in its class, and summed the 30 values to calculate the stand foliage area. Table $V$ presents the LAI values for each cohort and stand, and the total developed LAI (all-sided leaf area index). There was only a slight difference between the two older stands $(+3 \%)$, but the 5 year-old stand had a much lower LAI $(-40 \%)$.

\subsection{Vertical and horizontal distributions of foliage density}

This part of the work could not been performed on the Bray site in 1990 because the adequate architectural measurements were not measured by then. Figure 6 shows the vertical needle area density probability functions for both stands (26 year-old Bray site, 5 year-old L site) together with the measured values (bars). The vertical distributions of the one year-old needle density were similar for both stands. Most of the one year-old needle area density was located in the top third of the crown. On the opposite, the vertical distribution for the two year-old needles differed between the two stands, the foliage density being mainly located in the upper part of the crown for the 26 year-old stand, and mainly in the lower part of the crown for the 5 year-old stand. On the older stand, the three year-old NAD probability function was also 
Table IV. Parameters of the non linear models estimating individual crown foliage by needle age class (1, 2 or 3 year-old) and crown dimensions as a function of tree dimensions. The model for foliage area is CrLA $(i)=b 1 * D^{b 2} /$ age ${ }^{b 3}$, with CrLA $(i)$, crown leaf area of age $i$; age, stand age in year; $D$ either DLC, diameter under the living crown, in $\mathrm{cm}$ or DBH, diameter at breast height (1.3 $\mathrm{m})$, in $\mathrm{cm}$. The model for crown dimensions is $\mathrm{CrL}=b 1 * D^{b 2}$, with $\mathrm{CrL}$ either CrLgth, crown length $(m)$ or CrRad, crown maximum radius $(m)$. Numbers in parenthesis indicate the asymptotic standard error on the estimate.

\begin{tabular}{lccccc}
\hline Variable & $\begin{array}{c}\text { Diameter } \\
\mathrm{cm}\end{array}$ & \multicolumn{1}{c}{$\begin{array}{c}\text { Model parameters } \\
b 2\end{array}$} & \multicolumn{2}{c}{ RMS* } \\
\hline CrLA (1) & DLC & $0.312(0.093)$ & $2.204(0.185)$ & $0.404(0.103)$ & 52.11 \\
& DBH & $0.546(0.167)$ & $2.508(0.245)$ & $1.180(0.186)$ & 64.85 \\
CrLA (2) & DLC & $0.148(0.043)$ & $2.295(0.171)$ & $0.293(0.101)$ & 31.70 \\
& DBH & $0.234(0.070)$ & $2.708(0.226)$ & $1.160(0.176)$ & 37.26 \\
CrLA (3) & DLC & $17.588(1.475)$ & $1.895(0.267)$ & $1.895(0.267)$ & 4.28 \\
CrLgth & DBH & $7.854(0.418)$ & $2.308(0.297)$ & $2.308(0.297)$ & 3.88 \\
CrRad & DBH & $0.853(0.074)$ & $0.629(0.029)$ & - & 0.280 \\
\hline
\end{tabular}

*RMS = residual mean square
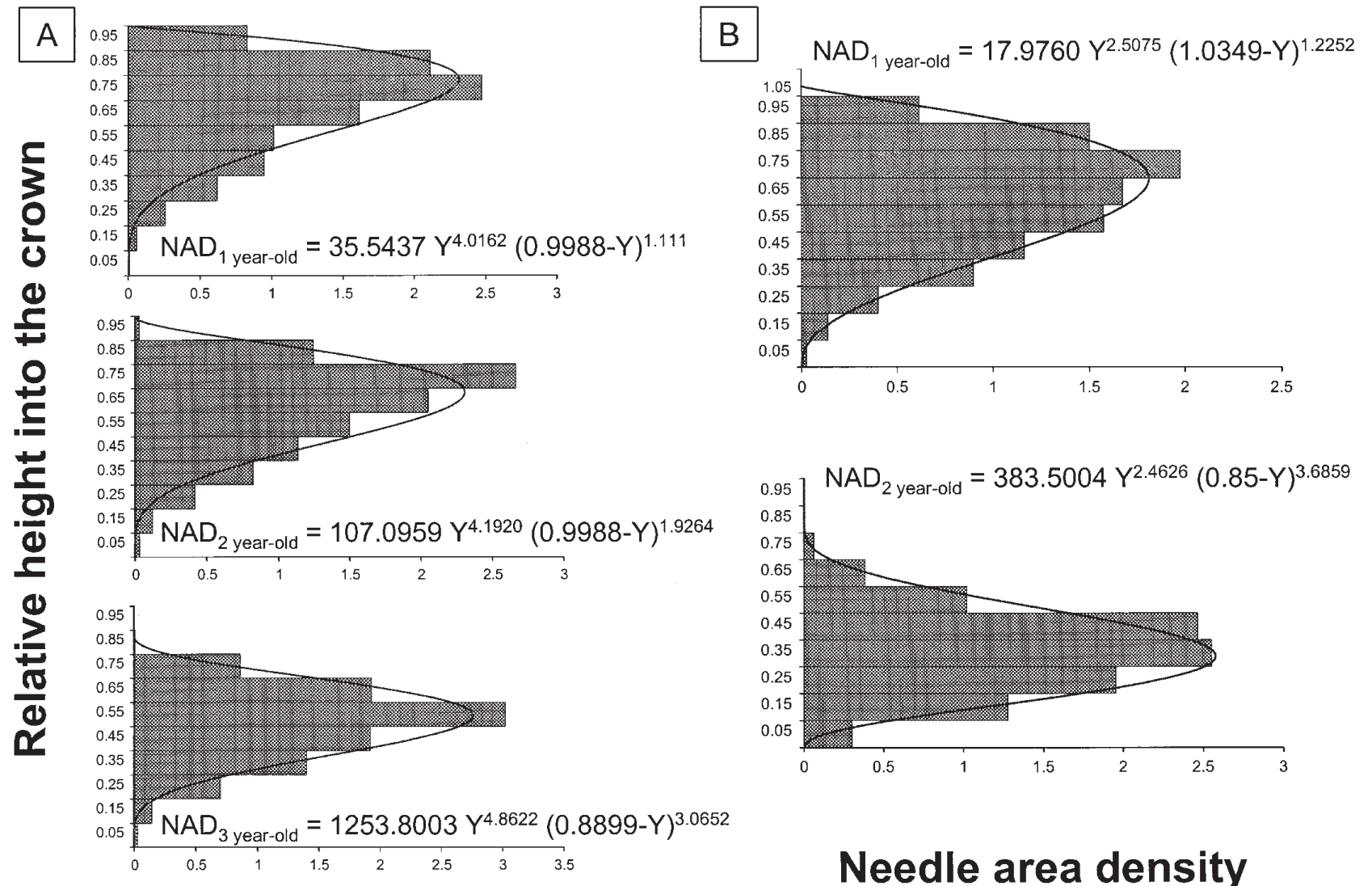

Figure 5. Vertical probability function of needle area density (NAD) as a function of relative height inside the crown $(0=$ bottom, $1=$ top). (A) 26 year-old stand (B) 5 year-old stand. Bars correspond to the data estimated with the branch models, solid lines correspond to the beta fittings. Top graphs correspond to the one year-old needles, middle graphs to the two year-old needles, bottom graphs to the three year-old needles. 
Table V. Summary of the stands characteristics and LAI (leaf area index) per stand and needle age as calculated using the crown level leaf area model with DBH and age as independent variables. LAI corresponds to the projected leaf area $\left(\mathrm{m}^{2}\right)$ per unit ground area $\left(\mathrm{m}^{2}\right)$. Developed LAI is all-sided leaf area per unit ground area $\left(\mathrm{m}^{2} \mathrm{~m}^{-2}\right)$. Values in parenthesis are standard errors of the mean.

\begin{tabular}{|c|c|c|c|c|}
\hline & & $\mathrm{L}$ & Bray 90 & Bray 95 \\
\hline Stand area & (ha) & 7 & 16 & 16 \\
\hline Plot area & (ha) & 5.51 & 4.70 & 4.70 \\
\hline Age & (year) & 5 & 21 & 26 \\
\hline Stocking density & $\left(\right.$ stem ha $\left.^{-1}\right)$ & 1178 & 829 & 621 \\
\hline Mean DBH & $(\mathrm{cm})$ & - & $21.02(3.97)$ & $26.03(4.74)$ \\
\hline Basal area & $(-)$ & - & 29.80 & 34.16 \\
\hline Mean height & $(\mathrm{m})$ & $3.19(0.43)$ & $13.88(1.01)$ & $17.63(1.21)$ \\
\hline Sample size & (tree) & 30 & 19 & 14 \\
\hline LAI 1 year-old & $\left(\mathrm{m}^{2} \mathrm{~m}^{-2}\right)$ & 0.81 & 1.14 & 1.11 \\
\hline 2 year-old & $\left(\mathrm{m}^{2} \mathrm{~m}^{-2}\right)$ & 0.56 & 0.96 & 0.99 \\
\hline 3 year-old & $\left(\mathrm{m}^{2} \mathrm{~m}^{-2}\right)$ & - & 0.30 & 0.22 \\
\hline LAI total & $\left(\mathrm{m}^{2} \mathrm{~m}^{-2}\right)$ & 1.37 & 2.40 & 2.32 \\
\hline Developed LAI & $\left(\mathrm{m}^{2} \mathrm{~m}^{-2}\right)$ & 3.52 & 6.17 & 5.96 \\
\hline
\end{tabular}

calculated: it was less asymmetric and most of the NAD was located at the middle of the crown (mid- relative height). On both stands, it appeared that the beta distributions (full line) fitted well on the foliage density data (histogram). Parameters varied with stand and needle age. The beta function used four parameters $(a 4>1$, top of the crown) since there were needles up to the top of the crown. All parameters were significantly different from zero (table III).

The horizontal probability functions of foliage density are presented in figure 7 . Density distributions differed little between the one and two year-old needle cohorts (parameters in table III) but were changing between the younger and the older stand. The younger trees foliage density was symmetrically distributed along the radius of the crown (one year-old needles) or even located nearer to the trunk (two year-old needles) whereas on the 26 year-old pines, it was located on the outer shell of the crown $(66 \%$ of the NAD between $0.65-0.95$ of relative radius). In the older trees, the three year-old NAD probability function (figure $7 A$ ) was symmetrical in the crown and centred around 0.5 relative radius. The horizontal profiles were well described using a 4 parameters beta function, allowing a non-zero value of the lower bound for the younger trees, and an upper bound greater than 1 for the 26 year-old trees.

\section{DISCUSSION}

The relationship that we obtained between branch foliage area and sapwood area at branch base (or $D_{10}^{2}$ ) is a classical result. Most studies attempting to develop equations to calculate branch foliage weight or area underlined a strong relationship between branch foliage and branch diameter or sapwood area $[3,10,12,15,22$, 25]. The positive correlation between foliage and sapwood area was expected: it corresponds to the equilibrium between sap-flow conducting area and transpiring surfaces $[26,35]$. Some of the studies concluded to the sufficiency of diameter or sapwood area alone to explain the variability of branch foliage [22] but they did not take into account the fact that in coniferous trees, branches are still increasing in diameter while ageing but not always in foliage biomass. Similarly, they ignored the discrepancy that exists between the foliage area borne by a young branch situated at the top of the canopy and the one borne by an older branch of the same diameter located in lower parts of the tree crown. Therefore, it was important to take into account that for a given branch diameter, branch foliage area decreased with increasing depth into the crown. Our use of the interaction between square diameter and relative height into the crown as an explicative variable improved considerably the leaf area predictions. The necessity of introducing the relative height into the crown was also underlined for other coniferous species like Pseudotsuga menziesii [15], Pinus taeda [3, 12], Tsuga heterophylla and Abies grandis [15]. However, the exact shape of the relationship was less consensual and varied from linear $[10,41]$ to non-linear relationships $[12,22,28]$, through $\log$ transformed relationships $[15,22]$. The non-linear equation presented in this paper participates to this diversity. The form of the selected model allowed to describe two phenomena. First, branch foliage was not only related to branch characteristics but also to trees and stands 

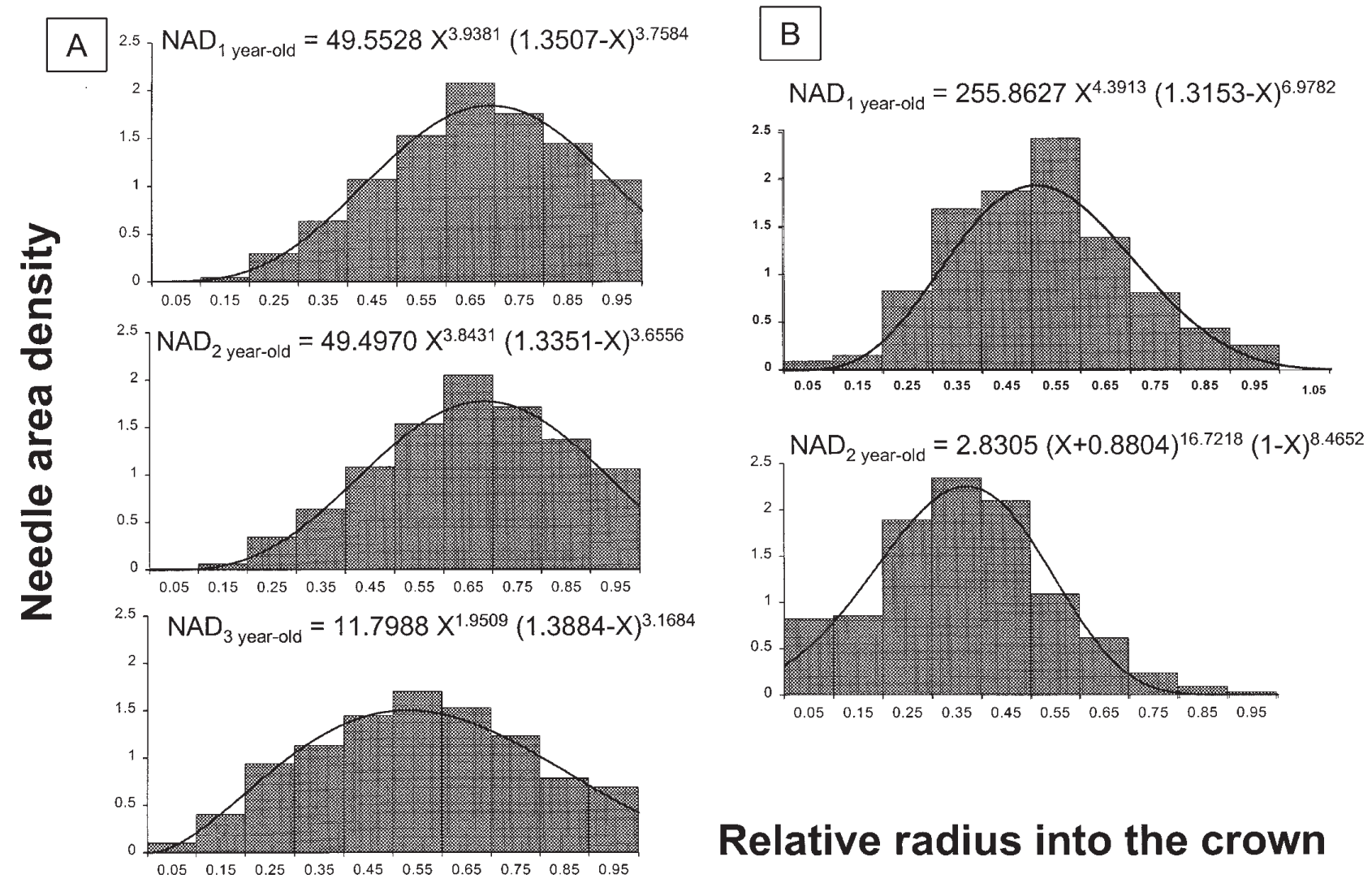

Figure 6. Horizontal probability function of needle area density (NAD) as a function of relative radius inside the crown $(0=$ trunk, $1=$ outer shell). (A) 26 year-old stand (B) 5 year-old stand. Bars correspond to the data estimated with the branch models, solid lines correspond to the beta fittings. Top graphs correspond to the one year-old needles, middle graphs to the two year-old needles, bottom graphs to the three year-old needles.

particularities: the use of a power function over the variable $D_{10}{ }^{2} \times H t_{\text {rel }}$ allowed us to adjust to the non exact correspondence between branch dimensions and branch foliage. Second, the larger foliage area observed on similar branches of the younger stand was certainly a consequence of the open canopy which allowed branch development between the tree lines, whereas the 21 and 26 year-old stands presented closed canopies. The changing in the parameters from one site to another (table II) allowed to describe the increasing gradient in foliage area for a same value of the variable $D_{10}^{2} \times H t_{\text {rel }}$ from the older to the younger stand.

The major drawback of our branch models was the under-estimation of calculated foliage area for the largest values of our range because these branches represented a large part of total crown leaf area. This bias in the model resulted partly from the data set: the larger leaf areas were corresponding to the biggest branches located at the bottom of the crown. However, on old branches, needle loss can be observed consecutively to the breaking (natural and/or consecutive to tree fall) of $3^{\text {rd }}$ order branches resulting in biased branch biomass measurements and to an unsatisfying estimation of larger foliage area. Finally, the use of the branch foliage model developed on the 26 year-old stand (figure 3 ) to estimate independent values of needle area measured on 27 year-old tree branches validated our model.

The loss of most of the three year-old needles certainly explained the difficulty to achieve a good allometric model for this cohort. Indeed, intra-annual litter falls measurements undertaken in our laboratory indicated important differences in the amount of needles fallen from one year to another, and consequently in the amount of old needles remaining on the trees. Annual variations in weather and particularly in water stress 
were showed to highly influence old-needle senescence $[9,32,38]$ in Pinus radiata and Pinus taeda.

At the tree level, the use of diameter at breast height to estimate tree total foliage area was widespread $[3,10$, 22]. However, the use of diameter or sapwood area under the living crown was also investigated $[12,17,22,26$, 36]: they confirmed our result that DLC performed better than DBH. However, the ratio of crown leaf area to sapwood area under the living crown (table III) was sitespecific and so it could not been used alone as an estimator of leaf area. Margolis et al. [26] explained that it corresponded to the limitations of allometric relationships and to the point where introducing a description of the hydraulic functioning of the tree would produce superior models. Though, the originality of our study was to show that although stocking densities and/or silvicultural history were quite different between the stands, very young pines and adult pines foliage behave in the same way (figure 4). The power function of tree age, which was introduced in the model, reflected that for a same DBH, younger trees presented larger crown foliage area. This parameter can be regarded as a stand vigour index. The LAI calculated on the 26 year-old stand using these equations was consistent with the PAI (plant area index) values obtained with light intercepting devices on the same stand (3.10, measurement done in early November 1995, Berbigier personal communication, 2.68-3.67 in 1991-1993 [4], 3-3.04 from July to October 1995 [14]). The higher PAI values could be attributed to the fact that light transmission through the canopy resulted not only from the foliage area but also from the woody parts of the crown. The LAI values (table $V$ ) matched with the bottom of the range indicated by Vose et al. [38] on different Pinus trees (developed LAI from 2.8 to 18.5$)$, but they remained consistent with maritime pine sparse crown. The low value of LAI on the 5 yearold stand was a consequence of the open canopy: at least half of the stand area was still uncovered by pines.

Concerning the crown structure models, it was developed as a rapid and useful tool to estimate crown dimensions which are requirements, as well as NAD functions, if one wants to obtain leaf area density profiles in tree crowns. A more complete and detailed analysis of crown structure still remains necessary to obtain a better tool. The choice of a beta function to describe needle area density probability functions was borrowed to the MAESTRO model and finally fitted well the data, both for horizontal and vertical profiles (figures 6, 7), provided that the function was not forced to be bounded between 0 and 1. Indeed, consequent foliage amounts were located on the limiting shell of the crown or close to the trunk for the younger trees and a 3-parameter function would have imposed the absence of foliage on both limits. It was already demonstrated that before canopy closure, the vertical foliage distribution was skewed downward and that it was skewed upward after canopy closure [38]. This can explain the differences in vertical profiles between the 5 and the 26 year-old trees. The shift towards the top of the crown observed for younger needles was quite characteristic of the coniferous growth pattern which approximately corresponded to an upward translation. Such a translation of the foliage amounts was observed between smaller and bigger Douglas-fir trees [25], between younger and older needle cohorts of Pinus radiata [39]. The gap between the one and two year-old NAD probability functions was more important for the 5 year-old stand, consecutively to the conjunction of a huge annual growth rate of the young tree $($ mean $=$ $80 \mathrm{~cm}$ year $^{-1}, \mathrm{SD}=29, \max =175 \mathrm{~cm}$ year $^{-1}, \min =$ $20 \mathrm{~cm} \mathrm{year}{ }^{-1}$ ) with the absence of crown recession (a consequence of the still open canopy). A similar phenomenon explained the shape of the horizontal profiles: the rhythmic growth of the branches resulted in the offset location of foliage density for the older trees, since $2^{\text {nd }}$ order needles $(29 \%$ of one and two year-old needle area) were located on the tips of the branches and $3^{\text {rd }}$ order needles $(53 \%)$ were mainly located on the younger whorls of the branch. On the contrary, the consequent contribution of trunk foliage (15\%, versus $5 \%$ for older trees) and $2^{\text {nd }}$ order foliage (37\%) contributed to maintain a high NAD closer to the trunk for the 5 year-old trees. However, we must note that the horizontal NAD probability profile was partly biased by the representation of branch shape using a circle arc: this regular shape drifted the central part of the branch towards the shell of the crown and consequently pulled leaf area away from the centre of the crown. This bias was all the more visible than a branch was long and old; therefore this phenomenon particularly affected the 26 year-old trees NAD profiles.

\section{CONCLUSION}

The present work successfully achieved the study of leaf area amounts and distributions in winter time (late November- early February) in the humid part of the Landes de Gascogne Forest, for different Maritime pine stand ages. The equations presented in this paper were specifically developed to locate the foliage area inside the crown together with its quantification. They enabled the estimation of leaf area for each needle cohort and for trees ranging from 5 to 26 year-old, at the branch, the tree and the stand level. However, we were forced to chain successive equations at the different scales, accumulating statistical errors at each step. To calculate these errors, it would need further consequent studies to solve complex matrices systems (Huet, personal 
communication). These estimations combined with architectural measurements led to a description of foliage density probability functions inside the crown (adapted for 5 and 26 year-old stands). It could be completed by an intermediate stand to obtain a similar evolution with stand age than the one obtain concerning tree foliage area.

However, all these results corresponded to the wintertime state of the trees: a dynamic study of foliage burst, growth and death should be undertaken to investigate intra-annual foliage variations. By now using the results presented in this paper, we can estimate crown dimensions and crown foliage area by needle age class from tree age and diameter at breast height. Then we can describe foliage location inside the crown using the probability functions of foliage density. These can be used to parameterise crown structural modules of light interception models [39] and to model carbon assimilation. They were used on Maritime pine to be part of a structure-function model that described the main primary production processes [6].

Acknowledgements: The authors thanks warmly N. Yahaya, A. Vinueza, F. Vauchel, P. Trichet, M. Sartore, E. Pegoraro, L. Maleyran, H. Lataillade, A. Lardit, C. Lambrot, F. Lagane, B. Issenhuth, M. Guédon, F. Danjon, J.P. Chambon, D. Bert, V.M. Bernard who took their turn to collect the different data sets. This work was supported by the European projects Euroflux and LTEEF-2, and the French project GIP-ECOFOR "Landes 2". The Bray site was used by courtesy of the Company "France-Forêts".

\section{REFERENCES}

[1] Bartelink H.H. a, A model of dry matter partitioning in trees, Tree. Physiol. 18 (1998) 91-101.

[2] Bartelink H.H. b, Simulation of growth and competition in mixed stands of Douglas-fir and beech, Ph.D. Thesis Landbouwuniversiteit Wageningen, Pays-Bas (1998) p. 222.

[3] Baldwin Jr. V.C., Peterson K.D., Burkhart H.E., Amateis R.L., Dougherty P.M., Equations for estimating loblolly pine branch and foliage weight and surface area distributions, Can. J. For. Res. 27 (1997) 918-927.

[4] Berbigier P., Bonnefond J.M., Measurements and modelling of radiation transmission within a stand of maritime pine (Pinus pinaster Aït.), Ann. Sci. For. 52 (1995) 23-42.

[5] Berbigier P., Loustau D., Diawara A., Étude microclimatique de l'effet de la sécheresse sur l'évaporation d'une plantation de Pin maritime à sous-bois de Molinie, Ann. Sci. For. 48 (1991) 157-177.

[6] Bosc A., Étude expérimentale du fonctionnement hydrique et carboné des organes aériens du Pin maritime (Pinus pinaster Aït) : intégration dans un modèle StructureFonction appliqué à l'analyse de l'autonomie carbonée des branches de la couronne d'un arbre adulte, Thèse de l’Université de Bordeaux II, (1999) pp. 192.

[7] Danjon F., Bert D., Godin C., Trichet P., Structural root architecture of 5-year-old Pinus pinaster measured by 3D digitising and analysed with AMAPmod, in Stokes A. (Ed.), Proc. Conf. "The supporting roots, Structure and Function", 2 - 24 July 1998, Bordeaux, France, 1999, in press.

[8] Danjon F., Sinoquet H., Godin C., Colin F., Drexhage M., Characterisation of the structural tree root architecture using 3D digitising and the AMAPmod software handling plant architecture, Plant and Soil 211 (2) (1999) 241-258.

[9] Dougherty P.M., Whitehead D., Vose J.M., Environmental influences on the phenology of pine, Ecol. Bull. 43 (1994) 64-75

[10] Dvorak V., Oplustilova M., Janous D., Relation between leaf biomass and annual ring sapwood of Norway spruce according to needle age-class, Can. J. For. Res. 26 (1996) 1822-1827.

[11] Fourcaud T., Blaise F., Reffye (de) P., Houllier F., Barthélémy D., Plant growth simulation based on ecophysiological processes. Influence of architectural on tree growth, Poc. Plant Biomechanics 1 (1997) 331-336.

[12] Gillespie A.R., Allen H.L., Vose J.M., Amount and vertical distribution of foliage in young loblolly pine trees as affected by canopy position and silvicultural treatment, Can. J. For. Res. 24 (1994) 1337-1344.

[13] Granier A., Loustau D., Measuring and modelling the transpiration of a maritime pine canopy from sap-flow data, Agric. For. Meteorol. 71 (1994) 61-81.

[14] Hassika P., Berbigier P., Bonnefond J.M., Measurement and modelling of the photosynthetically active radiation transmitted in a canopy of maritime pine, Ann. Sci. For. 54 (1997) 715-730.

[15] Kershaw Jr. J.A., Maguire D.A., Crown structure in western hemlock, Douglas-fir, and grand fir in western Washington: trends in branch-level mass and leaf area, Can. J. For. Res. 25 (1995) 1897-1912.

[16] Kremer A., Déterminisme génétique de la croissance en hauteur du Pin maritime (Pinus pinaster Aït.). I. Rôle du polycyclisme, Ann. Sci. For. 38 (2) (1981) 199-222.

[17] Landsberg J.J., Stand structure and microclimate, in: Milthorpe F.L. and Snaydon R.W. (Eds.), Physiological ecology of forest production, Ac. Press Inc., London, 1986, pp. 32-67.

[18] Laroussinie O., Introduction aux contributions sur les bases biologiques et physico-chimiques de la gestion durable des Landes de Gascogne, in : De la forêt cultivée à l'industrie de demain, Actes du $4{ }^{\text {ème }}$ Colloque Arbora, 20-21, novembre 1997, pp. 1-2.

[19] Le Dizès S., Cruiziat P., Lacointe A., Sinoquet H., Le Roux X., Balandier P., Jacquet P., A model for simulating structure-function relationships in walnut tree growth processes, Silva Fennica 31 (1997) 313-328.

[20] Lemoine B., Growth and yield of maritime pine (Pinus pinaster Ait): the average dominant tree of the stand, Ann. Sci For. 48 (1991) 593-611. 
[21] Lemoine B., Decourt N., Tables de production pour le pin maritime dans le sud-ouest de la France. R.F.F. XXI 1 (1969) 5-16.

[22] Lemoine B., Gelpe J., Ranger J., Nys C., Biomasses et croissance du pin maritime. Étude de la variabilité dans un peuplement de 16 ans, Ann. Sci. For. 43 (1) (1986) 67-84.

[23] Linder S., McMurtrie R.E., Lansberg J.J., Growth of Eucalypts: a mathematical model applied to Eucalyptus globulus, In: Crop Physiology of Forest Trees.Tigerstedt P.M.A., Puttonen P. and Koski V. (Eds.), Proceedings of an International Conference on Managing Forest Trees as Cultivated Plants held in Finland, July 23-28, University of Helsinki, (1984) 117-126.

[24] Loustau D., Domec J.C., Bosc A., Interpreting the variability of xylem sap flux density within the trunk of Maritime Pine (Pinus pinaster Ait.): application for calculating the water flow at the tree and stand levels, Ann. Sci. For. 55 (1998) 2946.

[25] Maguire D.A., Bennett W.S., Patterns in vertical distribution of foliage in young coastal Douglas-fir, Can. J. For. Res. 26 (1996) 1991-2005.

[26] Margolis H., Oren R., Whitehead D., Kaufmann M.R., Leaf area dynamics of conifer forests, in: Smith W.K. and Hinkley T.M. (Eds.), Ecophysiology of coniferous forests, Ac. Press Inc., San Diego, 1995, pp. 181-224.

[27] McMurtrie R.E., Leuning R., Thompson W.A., Wheeler A.M., A model of canopy photosynthesis and water use incorporating a mechanistic formulation of leaf $\mathrm{CO}_{2}$ exchange, For. Ecol. Man. 52 (1992) 261-278.

[28] Morales D., Jiménez M.S., González-Rodríguez A.M., Cermák J., Laurel forests in Tenerife, Canary Islands. II. Leaf distribution patterns in individual trees, Trees 11 (1996) 41-46.

[29] Perttunen J., Sievänen R., Nikinmaa E., Salminen H., Saarenmaa H., Väkevä J., LIGNUM: A tree model based on simple structural units, Ann. Bot. 77 (1996) 87-98.

[30] Porté A., Loustau D., Variability of the photosynthetic characteristics of mature needles within the crown of a 25year-old Pinus pinaster, Tree Physiol. 18 (1998) 223-232.

[31] Reffye P(de)., Fourcaud T., Balise F., Barthélémy D., Houllier F., A functional model of tree growth and tree architecture, Sylva Fennica 31 (3) (1997) 297-311.

[32] Schoettle A.W., Fahey T.J., Foliage and fine roots longevity of pines, Ecol. Bull. 43 (1994) 136-153.

[33] Stokes A., Martin F., Scriste S., Fourcaud T., Adaptation of tree roots to wind loading - The relationship between mechanical behaviour and wood formation, in Jeronimidis G. and Vincent J.F.V. (Eds.), Plant Biomechanics, university of Reading, 1997, pp. 339-347.

[34] Stokes A., Berthier S., Sacriste S., Martin F., Variations in maturation strains and root shape in root systems of Maritime pine (Pinus pinaster Ait.), Trees 12 (1998) 334339 .

[35] Valentine H.T., A carbon-balance model of tree growth with a pipe-model framework, in Dixon R.K., Meldahl R.S., Ruark G.A. and Warren W.G. (Eds.), Forest growth: process modeling of forest growth responses to environmental stress, Timber press, Portland, Oregon, 1990, pp. 33-40.

[36] Valentine H.T., Baldwin Jr. V.C., Gregoire T.G., Burkhart H.E., Surrogates for foliar dry matter in loblolly pine, For. Sci. 40 (3) (1994) 576-585.

[37] Vannière B., Tables de production pour les forêts françaises, Engref Nancy (Ed.), (1984) p. 158.

[38] Vose J.M., Dougherty P.M., Long J.N., Smith F.W., Gholz H.L., Curran P.J., Factors influencing the amount and distribution of leaf area of pine stands, Ecol. Bull. 43 (1994) 102-114.

[39] Wang Y.P., Jarvis P.G., Benson M.L., Two-dimensional needle-area density distribution within the crowns of Pinus radiata, For. Ecol. Man. 32 (1990) 217-237.

[40] Wang Y.P., Jarvis P.G., Influence of shoot structure on the photosynthesis of Sitka spruce (Picea sitchensis), Func. Ecol. 7 (1993) 433-451.

[41] Webb W.L., Ungs M.J., Three dimensional distribution of needle and stem surface area in a Douglas-fir, Tree Physiol. 13 (1993) 203-212.

\section{APPENDIX 1.}

Table A1. List of symbols used in the text, presented in alphabetical order.

\begin{tabular}{|c|c|c|}
\hline Symbol & Units & Description \\
\hline$\alpha$ & $\mathrm{rad}$ & angle between the trunk and the branch chord \\
\hline BrLA & $\mathrm{m}^{2}$ & branch leaf area \\
\hline & $\mathrm{m}$ & length of the branch chord \\
\hline CrLA & $\mathrm{m}^{2}$ & crown leaf area \\
\hline CrLgth & $\mathrm{m}$ & length of the crown \\
\hline CrRad & $\mathrm{m}$ & maximum radius of the crown \\
\hline & $\mathrm{cm}$ & diameter of a $1^{\text {st }}$ order growth unit \\
\hline$D_{j}$ & $\mathrm{~cm}$ & diameter of a $2^{\text {nd }}$ order internode $j$ \\
\hline$D_{10}^{\prime}$ & $\mathrm{cm}$ & branch diameter at $10 \mathrm{~cm}$ of the bole \\
\hline DBH & $\mathrm{cm}$ & tree diameter at breast height \\
\hline DLC & $\mathrm{cm}$ & tree diameter under the living crown \\
\hline$H$ & $\mathrm{~m}$ & insertion height of a branch on the trunk \\
\hline$H t_{\text {rel }}$ & - & normalised length of the crown \\
\hline$L^{\text {rel }}$ & $\mathrm{m}$ & length of a $1^{\text {st }}$ order growth unit \\
\hline$L_{\mathrm{b}}$ & $\mathrm{m}$ & length of the branch \\
\hline$L_{j}^{\mathrm{b}}$ & $\mathrm{m}$ & length of a $2^{\text {nd }}$ order internode $j$ \\
\hline$L_{j x}^{J}$ & $\mathrm{~m}$ & $\begin{array}{l}\text { length of the orthogonal projection of } \\
\text { internode } j \text { on the horizontal axis }\end{array}$ \\
\hline$L_{j y}$ & $\mathrm{~m}$ & $\begin{array}{l}\text { length of the orthogonal projection of } \\
\text { internode } j \text { on the vertical axis }\end{array}$ \\
\hline$L A_{j}$ & $\mathrm{~m}^{2}$ & $\begin{array}{l}\text { leaf area borne by the } 2^{\text {nd }} \text { order whorl } j \\
\text { and internode } j\end{array}$ \\
\hline LAI & $\mathrm{m}^{2} \mathrm{~m}^{-2}$ & leaf area index (needles alone) \\
\hline $\mathrm{NAD}_{j}$ & - & $\begin{array}{l}\text { needle area density borne by the } 2^{\text {nd }} \text { order } \\
\text { whorl } j \text { and internode } j\end{array}$ \\
\hline PAI & $\mathrm{m}^{2} \mathrm{~m}^{-2}$ & $\begin{array}{l}\text { plant area index (including needles and } \\
\text { woody axis) }\end{array}$ \\
\hline SLA & $\mathrm{m}^{2} \mathrm{~kg}^{-1}$ & specific leaf area \\
\hline$X_{j}$ & $\mathrm{~m}$ & abscissa of the $2^{\text {nd }}$ order whorl $j$ \\
\hline$X_{\mathrm{rel}}^{J}$ & - & normalised radius of the crown \\
\hline$Y_{j}^{\text {rel }}$ & $\mathrm{m}$ & ordinate of the $2^{\text {nd }}$ order whorl $j$ \\
\hline
\end{tabular}

